Original Research

\title{
Premarital Counseling Affects Primigravidas' Knowledge and Attitude on Reproductive and Sexual Health
}

\author{
Rika Ortiningsih ${ }^{1}$, Kasiati Kasiati ${ }^{2}$ and Samsriyaningsih Handayani ${ }^{3}$ \\ ${ }^{1}$ Midwifery Study Program, Faculty of Medicine, Universitas Airlangga, Surabaya, Indonesia \\ ${ }^{2}$ Sutomo Midwifery Study Program, Poltekkes Kemenkes Surabaya, Indonesia \\ ${ }^{3}$ Department of Public Health and Preventive Medicine, Faculty of Medicine, Universitas Airlangga, Surabaya, \\ Indonesia
}

\section{ABSTRACT}

Introduction: Unplanned pregnancy has been a worldwide issue, many of which end as unplanned abortions, miscarriages and deliveries. One-time premarital reproductive and sexual health counseling has been chosen as a program; however, its later effect on knowledge and attitude has not been evaluated. This study aimed to analyze the effectiveness of such premarital counseling for prospective brides on their knowledge and attitude during their first pregnancy.

Methods: The exposed group of 20 and control group of 40 primigravida participants were selected consecutively. Questionnaires were distributed online using Google Form application to participants to gather data on premarital counseling attendance in the past, and current knowledge and attitude. The influences were tested with logistic regressions at the significance level $(\alpha)$ of 0.05 .

Results: There was influence of sexual and reproductive health counseling for the bride and groom on the knowledge ( $\mathrm{p}=0.036 \mathrm{OR}=8.48095 \% \mathrm{CI}=$ $1.153-62.346)$ and the attitude $(\mathrm{p}=0.020$ OR $=5.41195 \% \mathrm{CI}=1.311$ 22.329).

Conclusion: Premarital sexual and reproductive health counseling influenced primigravidas' knowledge and attitude. The counselling should be intensified and extended to other cities to improve knowledge and attitude of primigravidas. Studies are needed to measure the effect of primigravidas' knowledge of and attitude toward reproductive and sexual health on the outcome of the pregnancy.
\end{abstract}

\section{ARTICLE HISTORY}

Received: August 14, 2020

Accepted: March 12, 2021

\section{KEYWORDS}

attitude; knowledge; sexual and reproductive health; premarital counseling

\section{CONTACT}

Samsriyaningsih Handayani $\triangle$ samsri.handayani@gmail.com $\equiv$ Department of Public Health and Preventive Medicine, Faculty of Medicine, Universitas Airlangga, Surabaya, Indonesia

Cite this as: Ortiningsih, R., Kasiati, K., \& Handayani, S. (2021). Premarital Counseling Affects Primigravidas' Knowledge and Attitude on Reproductive and Sexual Health. Jurnal Ners, 16(1). 49-53. doi:http://dx.doi.org/10.20473/jn.v16i1.24101

\section{INTRODUCTION}

Unplanned pregnancy has been a worldwide issue, many of which end as unplanned abortions, miscarriages and deliveries (Omani-Samani et al., 2019). Sexual and reproductive health counseling is an approach to increase the knowledge and attitudes of the prospective bride and groom in order to plan and prepare for a healthy pregnancy and to give birth to a quality future generation (Kemenkes, 2018). Premarital counseling materials include the philosophy of marriage, gender inequality and marriage, information about pregnancy, childbirth, postpartum phase, sexually transmitted infections, early detection of cervical cancer, and marriage myths. The effectiveness of counseling immediately after counseling has been studied (Amalia and Siswantara, 2018). However, the effectiveness of prenuptial counseling on their knowledge and attitude just before their first pregnancy starts is not widely known. The knowledge and attitude of primigravidas reflect their knowledge and attitude just before their first pregnancy.

Since the issuance of the Surabaya Mayor's Instruction in 2017, every prospective bride has to 
take part in the premarital program (Walikota Surabaya, 2017). So it is expected that there is $100 \%$ community participation as the prospective brides are required to get a proof from the health authority before they are eligible to register their marriage. However, based on information from midwives in the preliminary interviews, there are still prospective brides who do not receive reproductive and sexual health education for the prospective bride and groom because they are migrants from outside Surabaya. Gading and Wonokusumo Health Centers (Puskesmas) of Surabaya were chosen as the location of this research because both centers have implemented sexual and reproductive health education programs for prospective brides and had the most first visits (K1) in Surabaya. According to the Surabaya City Health Profile (Dinas Kesehatan Surabaya, 2018), the first visit of pregnant women at Puskesmas Gading reached 1473, and at Puskesmas Wonokusumo reached 1120 . This study aimed to analyze the effectiveness of such premarital counseling for prospective brides on their knowledge and attitude during their first pregnancy.

\section{MATERIALS AND METHODS}

This was a retrospective cohort study. Data collection was from February-June 2020, and began with identifying primigravidas with and without experience with premarital counselling in the past, followed by measuring their current knowledge and attitude on sexual and reproductive health.

The population of this study was all primigravidas in Puskesmas Gading and Puskesmas Wonokusumo Surabaya.

The research sample was primigravidas at Puskesmas Gading and Puskesmas Wonokusumo Surabaya in February-June 2020 meeting the following inclusion criteria: primigravida and minimum education of junior high school.

The sample size was calculated using the Fleiss formula and the sample size calculation used data from Anisafitri's research (Anisafitri, 2019). The calculated sample size of the exposed group was 20 . Telephone numbers of primigravidas were provided by both puskesmases. The proportion of primigravidas exposed and unexposed to counselling who were willing to enroll in the study were $1: 2$, hence the proportion of sample sizes were 1:2. Sample was selected consecutively.

From May to June 2020, prospective respondents were contacted by telephone and guided to fill out an online Google Form to obtain data on participation in sexual and reproductive health counseling for future brides in the past, and knowledge and attitudes during this first pregnancy. Knowledge was measured with 10 closed-ended questions regarding sexual and reproductive health for the prospective bride and groom and attitudes were measured with 10 closedended questions on a 4-point Likert scale. Knowledge was categorized as good if the respondent could answer $81-100 \%$ of questions correctly, and categorized as poor if they answered correctly less than $81 \%$. Attitude was categorized as favorable if the $\mathrm{T}$-Score more than mean of $\mathrm{T}$ and unfavorable if the $\mathrm{T}$ Score less than mean of T (Azwar, 2013). The authors formulated a questionnaire based on a guide book by the Ministry of Health's (2018) "Kesehatan Reproduksi dan Seksual bagi Calon Pengantin" (Sexual and Reproductive Health for Prospective Bride and Groom). The questionnaire was tested for its reliability and validity. Cronbach's alpha value for the reliability of the knowledge questionnaire was 0.794 and for attitude was 0.797. The p-values obtained through Pearson's product moment correlation test in the knowledge questionnaire validity test ranged from 0.915 to 0.999 , while for attitudes they ranged from 0.998 and 1.000. Cut-off values for age, age at marriage and length of marriage were means. Level education of college/university was categorized as high, and junior and high schools as low. Bivariate and multivariate analysis with logistic regression was performed with the help of SPSS 26.0 for windows with a significance level of 0.05 .

Research ethics acceptance letter no. 97 / EC / KEPK / FKUA / 2020 was obtained from the Health Research Ethics Commission of the Faculty of Medicine, Airlangga University on April 27, 2020.

\section{RESULTS}

Ranges of participants' age was 19 to 34 years old, age at marriage was 18 to 34 years, and length of marriage was 2 to 156 months. Means of respondents' age (24 years), age at marriage (23 years), and length of marriage ( 9 months) were used as cut-off values for dichotomized data. The highest level of education is masters graduate $(1.6 \%)$. Level of education was considered as low if it was junior or senior high school and high if it was diploma or bachelor (Table 1).

At the time of interviews, there were no differences in respondents' characteristics (all $p$ values $>0.05$ ). The mean of respondents' score of knowledge (6.78) was used as the cut-off value of dichotomized categories (good and poor). Attitude was categorized as favorable if the T-Score more than mean of $\mathrm{T}$ and unfavorable if the $\mathrm{T}$ Score less than mean of T. The mean of T-score was 32. Scores of 32 or greater were considered as favorable, while $\mathrm{T}$ scores of less than 32 were considered as unfavorable.

The highest scores of knowledge in control and exposed groups were 3 (7.5\% respondents) and 14 (70\% respondents), respectively. The highest scores of attitude in control and exposed groups were 14 (35\% participants) and 11 (55\% participants). The lowest scores of knowledge in control and exposed groups were 37 (92.5\% respondents) and 14 (70\% respondents), respectively. The lowest scores of attitude in control and exposed groups were 26 (65\% participants) and nine (45\% participants).

Table 3 shows the frequency distribution of sexual and reproductive health knowledge and attitude 
Table1. Respondent Characteristics

\begin{tabular}{|c|c|c|c|c|}
\hline \multirow[t]{2}{*}{ Characteristics } & Exposed group & Control group & \multirow[t]{2}{*}{$\mathbf{X}^{2}$} & \multirow[t]{2}{*}{$p$-value } \\
\hline & n (\%) & $\mathrm{n}(\%)$ & & \\
\hline \multicolumn{5}{|l|}{ Age } \\
\hline$\leq 24$ years old & $16(80)$ & $17(42.5)$ & 0.051 & 0.822 \\
\hline$>24$ years & $4(20)$ & $23(57.5)$ & & \\
\hline \multicolumn{5}{|l|}{ Age at marriage } \\
\hline$\leq 23$ years & $17(85)$ & $21(52.5)$ & 0.065 & 0.798 \\
\hline$>23$ years & $3(15)$ & $19(47.5)$ & & \\
\hline \multicolumn{5}{|c|}{ Length of marriage } \\
\hline$\leq 9$ months & $11(55)$ & $19(47.5)$ & 1818 & 0.178 \\
\hline$>9$ months & $9(45)$ & $21(52.5)$ & & \\
\hline \multicolumn{5}{|l|}{ Education } \\
\hline Low & $17(85)$ & $21(52.5)$ & 0.065 & 0.798 \\
\hline High & $3(15)$ & $19(47.5)$ & & \\
\hline
\end{tabular}

Table 2. Descriptive Statistics of Knowledge and Attitude

\begin{tabular}{lcccccc}
\hline & Minimum & Maximum & Mean & Standard deviation & Median & Mode \\
\hline Knowledge & 3 & 9 & 6.78 & 1.708 & 7 & 8 \\
Attitude & 29.30 & 65.80 & 49.98 & 9.97 & 52.70 & 52.70 \\
\hline
\end{tabular}

Table 3. Frequency Distribution of Sexual and Reproductive Health Knowledge and Attitude among Primigravida.

\begin{tabular}{ccccc} 
& Exposed group & Control group & \multirow{2}{*}{$\mathbf{X}^{2}$} & P values \\
\cline { 2 - 3 } & $\mathbf{n}(\%)$ & $\mathbf{n}(\%)$ & & 0.014 \\
\hline Knowledge & $6(30)$ & $3(7.5)$ & 6 & \\
\hline Good & $14(70)$ & $37(92.5)$ & & \\
\hline Poor & $20(100)$ & $40(100)$ & & 0.14 \\
\hline Attitude & $11(55)$ & $14(35)$ & 2.16 & \\
\hline Favorable & $9(45)$ & $26(65)$ & & \\
\hline Unfavorable & $20(100)$ & $40(100)$ &
\end{tabular}

Table 4. The Effect of Sexual and Reproductive Health Counseling for Prospective Brides, Age, Age at Marriage, Length of Marriage and Education on Knowledge of Primigravidas.

\begin{tabular}{lcccccc}
\hline & \multirow{2}{*}{ Unadjusted OR } & $\begin{array}{c}\text { P- } \\
\text { value }\end{array}$ & \multirow{2}{*}{ Adjusted OR } & \multirow{2}{*}{ p-value } & \multicolumn{2}{c}{ 95\% CI of adjusted OR } \\
\cline { 5 - 7 } & & & & Lower bound & Upper bound \\
\hline Premarital counselling & 5.286 & 0.031 & 8.480 & 0.036 & 1.153 & 62.346 \\
Age & 0.120 & 0.053 & 0.000 & 0.999 & 0.000 &. \\
Age at marriage & 0.179 & 0.117 & 66281752.37 & 0.999 & 0.000 &. \\
Length of marriage & 0.769 & 0.718 & 0.294 & 0.228 & 0.040 & 2.148 \\
Education & 1.143 & 0.855 & 0.989 & 0.989 & 0.197 & 4.969 \\
Constant & & & 0.191 & 0.021 & & \\
\hline
\end{tabular}

Table 5. The effect of sexual and reproductive health counseling for prospective brides, age, age at marriage, length of marriage and education on attitude of primigravidas.

\begin{tabular}{lcccccc}
\hline & Unadjusted OR & \multirow{2}{*}{ P-value } & \multirow{2}{*}{ Adjusted OR } & p-value & \multicolumn{2}{c}{ 95\% CI of adjusted OR } \\
\cline { 5 - 7 } & & & & & Lower bound & Upper bound \\
\hline Premarital counseling & 3.115 & 0.045 & 5.411 & 0.020 & 1.311 & 22.329 \\
Age & 0.933 & 0.895 & 1.265 & 0.828 & 0.153 & 10.481 \\
Age at marriage & 0.952 & 0.928 & 1.160 & 0.894 & 0.131 & 10.264 \\
Length of marriage & 0.662 & 0.433 & 0.321 & 0.088 & 0.087 & 1.187 \\
Education & 1.562 & 0.401 & 1.326 & 0.625 & 0.427 & 4.121 \\
Constant & & & 0.523 & 0.206 & & \\
\hline
\end{tabular}

among primigravida's. A bivariate test shows that there was a difference of knowledge between the exposed and control groups. However, there was no difference of attitude between both groups.

Table 4 reveals that, after controlling for age, age at marriage, length of marriage and education, those who attended sexual and reproductive health counseling were 8.480 times significantly higher than those who did not to have a better knowledge. As shown in Table 4, all other variables did not influence knowledge ( $\mathrm{p}$ values $>0.05$ ).

Table 5 shows that those who attended sexual and reproductive health counseling were 5.411 times significantly higher than those who did not to have favorable attitude. As shown in Table 5, all other variables did not influence attitude ( $\mathrm{p}$ values $>0.05$ ). 
Although in bivariate test the attitude did not differ between control and exposed groups ( $p=0.14$ ), in multivariate analysis after controlling for age, age at marriage, length of marriage, and education, attitude was influenced by premarital counselling $(p=0.02)$.

\section{DISCUSSION}

Most of the respondents in this study were migrants from outside Surabaya, so it was found that most respondents did not attend sexual and reproductive health counselling when they were prospective brides and grooms, while they attended antenatal care in Surabaya later on. This explains why there were pregnant women in Surabaya who did not get premarital counselling.

\section{Knowledge of reproductive and sexual health among primigravidas}

The results showed that most primigravida mothers were in the poor knowledge category, namely $70 \%$ in the exposed group and $92.5 \%$ in the control group. Poor knowledge about reproductive and sexual health can be caused by educational factors. In the research results, most of the primigravida mothers were in the category of primary and secondary education. Education is an effort to provide insight and knowledge to someone. The level of a person's education also affects the acceptance of information; people with higher education are easier to accept new information (Notoatmodjo, 2014). However, it is not proved in this study. The results of this study are not in line with research at Pucang Sewu Health Center Surabaya (Amalia and Siswantara, 2018) which shows that most respondents $(59.3 \%)$ have sufficient knowledge, $28.2 \%$ have good knowledge, and $12.5 \%$ have less knowledge. Amalia and Siswantara's (2018) findings suggest that influence by the existence of sexual and reproductive health education for the prospective bride and groom, the knowledge can be also affected by the level of education, which is not the case in this study. This difference can be caused by different data collection times, where. in the research by Amalia and Siswantara (2018), it was carried out on prospective brides after receiving counseling and in this study it was carried out during primigravida pregnancy.

\section{Attitude toward reproductive and sexual health among primigravidas}

The results showed that $55 \%$ of primigravida mothers in the exposed group were in the positive attitude category and $65 \%$ in the control group in the negative attitude category. According to attitude theory, attitude is an individual's reaction or response to an object (Azwar, 2013). A person's attitude is influenced by several factors, namely personal experience, the influence of others who are considered important, cultural influence, mass media, education, and emotional factors. These factors will influence the attitude of primigravida mothers. The results of this study are in line with Dhamayanti, (2020) which show that the majority of respondents have a positive attitude toward reproductive health as many as $27(87.1 \%)$. Another study by Susanti et al. (2018)showed that the attitude of the majority of respondents toward reproductive health has a positive attitude as many as 29 respondents (76.3\%). Differences in sexual and reproductive health attitudes for prospective brides to primigravida mothers can be influenced by several factors, one of which is education (Azwar, 2013). In this study, the highest levels of education were found at the primary and secondary levels, namely $85 \%$ of the exposed group and $52.5 \%$ of the control group. The higher a person's education, the easier it is to receive information. Conversely, if someone has a low level of education it will hinder the development of attitudes toward receiving information (Irawati, 2018). So it can be concluded that the education level of primigravida mothers can influence how much information is obtained. If the information about pregnancy is good, it can support the attitude of primigravida mothers to carry out actions that refer to mothers in dealing with their pregnancy. The attitude of primigravida mothers in this study can be influenced by education level and age.

\section{The effect of sexual and reproductive health counseling on knowledge and attitudes among primigravidas}

There was an influence of reproductive health counseling and knowledge. The OR value of 8.480 indicates that reproductive health counseling improved primigravidas' knowledge. According to the theory of knowledge, knowledge is information obtained by humans from observations using the five senses they have (Notoatmodjo, 2014). The results of this study were supported by Amalia and Siswantara (2018) who explained that there was a relationship to the knowledge of the prospective bride and groom before and after receiving reproductive health education.

There was a relationship between reproductive health counseling and attitudes. The OR value of 5.411 indicates that reproductive health counseling improved primigravidas' attitude. According to attitude theory, attitude is an individual's reaction or response to an object (Azwar, 2013). A person's attitude is influenced by several factors, namely personal experience, the influence of others who are considered important, cultural influence, mass media, education, and emotional factors. These factors will influence the attitude of primigravida mothers. The results of this study are also supported by research by Purwaningsih (2017) which explains that there is a relationship between reproductive health education and attitudes in adolescents. The effectiveness of reproductive health counseling is determined by several factors, including educators, target factors and factors in the health education process. Because the respondent's health education and the process of 
health education are the same, the determining factors in this study were the target factors, including the age of the respondent and the information the respondent has obtained (Notoatmodjo, 2007).

The Covid-19 pandemic is happening in Indonesia, including in the city of Surabaya, affecting the data collection process that previously gave the questionnaire directly transferred offline using Google Form. Researchers who were planned to supervise filling out the questionnaire directly at the participants' respective homes were restricted to do so. Therefore, the data obtained may be not as good as planned due to factors that could not be predicted by the researcher.

\section{CONCLUSION}

Reproductive and sexual health counseling for future brides improves knowledge and attitude in primigravidas. Premarital sexual and reproductive health counseling for brides should be intensified to improve knowledge and attitude in their future first pregnancy. Studies are needed to measure the effect of primigravidas' knowledge of and attitude toward reproductive and sexual health on the outcome of the pregnancy.

\section{REFERENCES}

Amalia, R. and Siswantara, P. (2018) 'Efektivitas Penyuluhan Kesehatan Reproduksi pada Calon Pengantin di Puskesmas Pucang Sewu Surabaya', Jurnal Biometrika dan Kependudukan, 7(1), p. 29. doi: 10.20473/jbk.v7i1.2018.29-38.

Anisafitri, D. (2019) Hubungan antara mengikuti penyuluhan kesehatan reproduksi dan seksual bagi calon pengantin dengan frekuensi antenatal care dan luaran kehamilan.

Azwar, S. (2013) Sikap Manusia: Teori dan Pengunkuranya. Yogjakarta: Pustaka Belajar.

Faridha Dhamayanti (2020) Gambaran Sikap Dan Pelaksanaan Pemeriksaan Reproduksi Pada
Pasangan Pra Nikah. Universitas Muhammadiyah Surakarta.

Irawati (2018) 'Upaya Meningkatkan Pengetahuan Kesehatan Repsroduksi dan Seksual Siswi SMPN 10 Surabaya', E jurnal dinas Pendidikan Kota Surabaya, 6, pp. 1-11.

Kementerian Kesehatan RI (2018) 'Kesehatan Reproduksi dan Seksual Bagi Calon Pengantin'. Jakarta.

Notoatmodjo, s (2007) Promosi Kesehatan dan Ilmu Perilaku. Jakarta: PT Rineka Cipta.

Notoatmodjo (2014) Promosi Kesehatan dan Ilmu Perilaku. Jakarta: PT Rineka Cipta.

Omani-Samani, R. Ranjbaran, M. Mohammadi, M. Esmailzadeh, A. Sepidarkish M, Maroufizadeh, S. (2019) 'Impact of Unintended Pregnancy on Maternal and Neonatal Outcomes', Journal of Obstetrics and Gynecology of India, 69(2), pp. 136141. doi: 10.1007/s13224-018-1125-5.

Purwaningsih, E. (2017) Pengaruh Penyuluhan Kesehatan Reproduksi Terhadap Pengetahuan dan Sikap Tentang Seks Pra Nikah Pada Remaja Dusun Bembem Jetis Bantul Yogyakarta. Naskah publikasi. Univeristas aisyiyah.

Surabaya, D. K. (2018) Profil Kesehatan 2018. Surabaya: Germas. Available at: http://library1.nida.ac.th/termpaper6/sd/2554/ 19755.pdf.

Susansti, D. Rustam, Y. Doni, W. (2018) 'Pengaruh Pendidikan Kesehatan Pranikah Terhadap Pengetahuan Dan Sikap Calon Pengantin Di Lubuk Begalung Padang Tahun 2017', Jurnal Sehat Mandiri, 13(2), pp. 18-25. doi: 10.33761/jsm.v13i2.72

Walikota Surabaya (2017) 'Intruksi Walikota Surabaya No.1 Tahun 2017 Tentang Pelaksanaan Pemeriksaan Kesehatan dan Penyuluhan Kesehatan Reproduksi Calon Pengantin', (031). 